$\mathrm{Ni}$ 基超合金一方向凝固材の冷却孔周囲の微小き裂進展に及ぼす 高サイクルと低サイクル疲労負荷の重畳効果

與那國 優希* 吉崎 伸* 岡崎 正和**

\title{
Superimposed Effect of High Cycle Fatigue and Low Cycle Fatigue Loadings on Small Crack Propagation Around Cooling Hole in A Directionally Solidified Ni-base Superalloy
}

by

\author{
Yuki Yonakuni*, Shin Yoshizaki* and Masakazu OKazAKI**
}

\begin{abstract}
Recent introduction of renewable energy systems has impelled the land based gas turbine power generation systems to play two different types of roles: one is a role as base load system, the other is a role as power adjusting system. To cope with the latter role, it is necessary to take into account of thermal fatigue failure of the gas turbine components, where transient thermal stress is often a critical issue to be concerned. In this study, non-stationary induced thermal fatigue failure behavior of a superalloy was explored. At first, a new test equipment was developed so that high cycle non-stationary thermal fatigue loading can be superimposed on stationary low cycle thermo-mechanical fatigue (TMF) loading. By means of the testing equipment, the early growth of small cracks around the cooling holes was investigated under the superimposed condition in a directionally solidified Ni-base superalloy, where some cooling holes were artificially introduced for a simulation. The experimental works clearly demonstrated that the crack growth rate under the superimposed condition was significantly accelerated, compared with that under the stationary low cycle TMF loading. This behavior was discussed based on fracture mechanistic view point.
\end{abstract}

\section{Key words:}

Superalloy, Non-stationary and stationary thermo-mechanical fatigue loading, Cooling hole, Local thermal stress, Early growth of small crack, Superimposed loading

1. 緒言

$\mathrm{Ni}$ 基超合金は高温における優れたクリープ特性を有す るためガスタービン動翼などに幅広く用いられている. その一方で, 熱効率の向上のために発電用タービン入口 温度は年々上昇しており, $1700^{\circ} \mathrm{C}$ の領域にまで達してい る ${ }^{1) 55}$. この温度は $\mathrm{Ni}$ 基超合金単体の耐用温度よりも高 いため, ガスタービン翼には様々な冷却技術が導入され ている ${ }^{4), 5)}$. たとえば翼表面の多数の冷却孔から圧縮空気 を噴出させることで翼周りに冷却フィルムを形成させ， 翼壁表面温度を許容值以下に保っている．翼冷却システ ムは高度化・複雑化の一途をたどっている，その一方で 冷却孔周りにおいては温度勾配に起因した熱応力が生じ ることからこれまで以上の温度勾配が生じたときには 従来の知見からは想定しがたい破損を生じることも懸念 されている ${ }^{1), 6)}$.

一方, 近年では, 従来の化石然料や原子力エネルギシ ステムに加えて再生可能エネルギが世界中に広がってい る. 再生可能エネルギシステムの出力は季節や天候に強 く依存するため, それらがいったん電源系統に接続され ると, 発電用ガスタービンは頻繁かつ急激な負荷変動を 余儀なくされる。この変動が顕著でかつ高速である場合
には，これまで特に配慮されてこなかった因子による熱 疲労破損, 寸なわち「構造体の過渡的応答に起因した熱 応力（熱過渡応力）による破損」が懸念される 6),7). しか しこれについて実証した研究はごく限られている6) 以上の背景から, 本研究では冷却構造を有するガスタ 一ビン翼の泠却孔周りの熱疲労破損に注目した. 調查に あたって, はじめに, 起動・停止を想定した定常的低サ イクル熱機械的疲労 (LCF) 負荷の上に, 冷却孔周りの温 度勾配と熱変動により誘起される過渡的（non-stationary） な高サイクル熱疲労（HCF）負荷が重畳された状態を模 擬できる試験装置を試作した。つぎにこの試験装置と Ni 基超合金製の試験片を用いて，応力集中部位となる冷却 孔周りの破損挙動について, 特に温度勾配に誘起される LCF 負荷と HCF 負荷の重畳効果に焦点をあて実験的に調 査した.

\section{2. 実環境模擬試験装置}

\section{$2 \cdot 1$ 実環境模擬試験装置の概要}

本研究では, 起動・停止を想定した定常的低サイクル 熱機械的疲労 (LCF) 負荷の上に, 冷却孔周りの温度勾配 と熱変動により誘起される過渡的（non-stationary）な高サ イクル熱疲労 (HCF) 負荷が重畳された状態を模擬でき

$\dagger$ 原稿受理 平成30年 7月 9日 Received July 9, 2018 @2019 The Society of Materials Science, Japan

* 学生会員 長岡技術科学大学大学院 干940-2188 長岡市上富岡町 Nagaoka University of Tech., Kamitomioka-machi, Nagaoka 940-2188.

** 正 会 員 長岡技術科学大学 $7940-2188$ 長岡市上富岡町

Nagaoka University of Tech., Kamitomioka-machi, Nagaoka 940-2188. 
る試験装置を文献 8)のものをベースに改良・試作した ${ }^{8)}$. 試験装置の概略図を Fig.1 に示す。ここでは試験片に加工 した冷却孔から圧縮空気を噴出させることでコールドス ポットを人工的に作り出し，その上で熱機械的負荷を油 圧サーボ試験機により加える方式としている，装置の基 本的原理は文献 8）と類似であるが，文献 8)では定常的に 一定量流していた圧縮空気の流れを，ファンクションジ エネレータを介してプログラムした波形に従って間欠的 に流せるようにしたもので，試験片の過渡的な熱応答に よって生ずる高サイクル熱疲労負荷を模擬できるように したものである.

\section{$2 \cdot 2$ 試験片および実験条件}

供試材は CM247LC 一方向凝固材（DS 材）とした。試 験片形状を Fig.2 に示す. 中空円筒状の試験片の標点部中 央およびそこから長手方向に $7 \mathrm{~mm}$ 離れた位置に合計 $3 つ$ の模擬冷却孔（ $\phi 2 \mathrm{~mm})$ を加工しており，3つの穴を通じ て圧縮冷却空気を試験片内側から外側に向かって噴出さ せる.ここで DS 材の負荷軸方向は結晶方位 $<001>$ から $5^{\circ}$ 以内となっている.

本研究では 2.1 節で述べた実環境模擬試験装置を用い て，低サイクル熱機械的疲労負荷（以下，LC-TMF)，な らびに，LC-TMFの上に高サイクル熱疲労負荷 (HCF) を 重畳させた疲労試験（以下，LC/HC-TMF）の 2 種類を実 施した. LC-TMF 試験では Fig.3(a)に示すような In-Phase 型の LC-TMF 負荷を与えた。この試験中は常時冷却空気

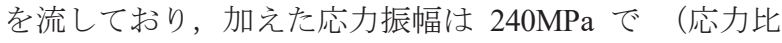
$\mathrm{R}=0$ ）周波数は $1 / 240 \mathrm{~Hz}$ である. 一方, $\mathrm{LC} / \mathrm{HC}-\mathrm{TMF}$ 試験 では LC-TMF サイクル中の外力保持期間中に冷却空気の 流れを間欠的に閉鎖させる方式とした。この場合，冷却 空気が流れていない期間中（Fig.3(b)中の点 P） は試験片 の遠方部と冷却孔部はほぼ同じ温度となる一方で，それ が流れている期間の最終点（Fig.3(b)の点 $\mathrm{P}^{\prime}$ ） では冷却

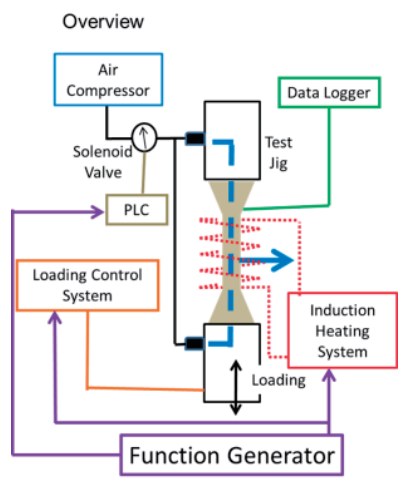

Fig.1 Illustration of a new test system.
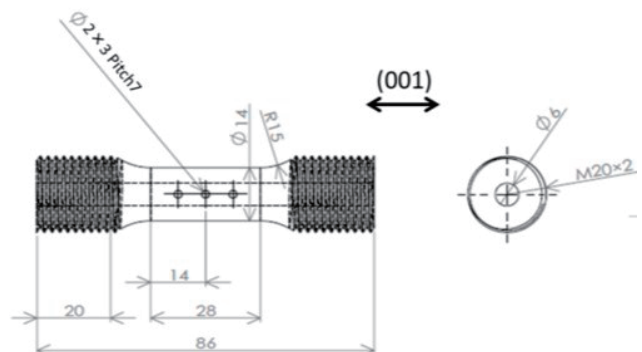

Fig.2 Geometry of hollow specimen with cooling holes.
孔周囲が強制的に冷却され，遠方部との温度差が顕著に なる (後述の Fig.5 参照). 本研究では冷却空気の停止の 周期を $6 \mathrm{~s}$ として，空気流量は $100 \mathrm{~N} 1 / \mathrm{min}$ とした。 そして 冷却空気停止の回数 $\boldsymbol{n}$ は実験変数とした（n=0 500 サイ クル).周期を $6 \mathrm{~s}$ 間隔としたのは, 冷却空気流の中断期間 をこの周期とすることにより，冷却孔周囲の温度が試験 片遠方部の温度になることが実験的に確かめられたから である，なお，一連の疲労試験実施中においては，冷却 孔付近の温度は放射温度計によりモニターしている。

冷却孔周囲の温度分布を調査寸るために，Fig.4 に示す 点 1 8 の位置に $\mathrm{K}$ 型熱電対を設け, 冷却孔近傍の温度は 冷却孔円周に接する位置に設けた熱電対により測定した (ただし, 熱電対の線径による制約があるため, 最大 $0.5 \mathrm{~mm}$ 離れている可能性がある). Fig.5 に Fig.3(b)中の点 P' に おける試験片内温度の計測結果を示す。ここでは試験片 制御位置の最高温度を $\boldsymbol{T}_{\boldsymbol{c}, \boldsymbol{m a x}}=900^{\circ} \mathrm{C}$, 最低温度を $\boldsymbol{T}_{\boldsymbol{c}, \boldsymbol{m i n}}=300^{\circ} \mathrm{C}$ としている. Fig.5 から冷却孔遠方位置に対し, 周方向では約 $100^{\circ} \mathrm{C}$ の, 軸方向では約 $130^{\circ} \mathrm{C}$ 温度勾配が 冷却孔周辺で生じていることが確認できる.

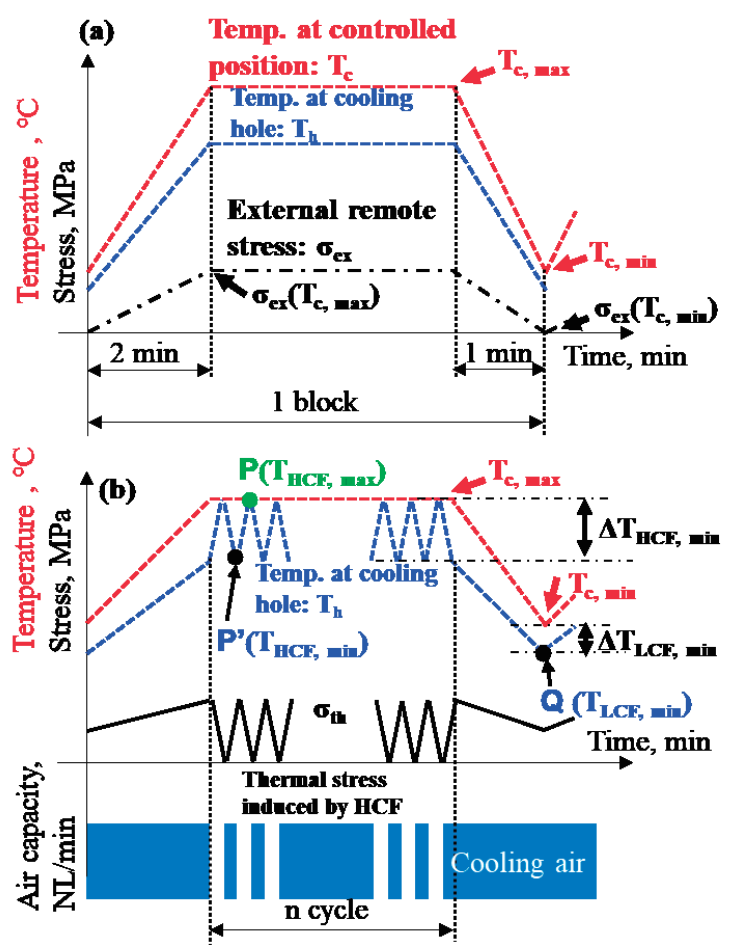

Fig.3 (a) Illustration of waveform in the LC-TMF test, (b) LC/HC-TMF test.

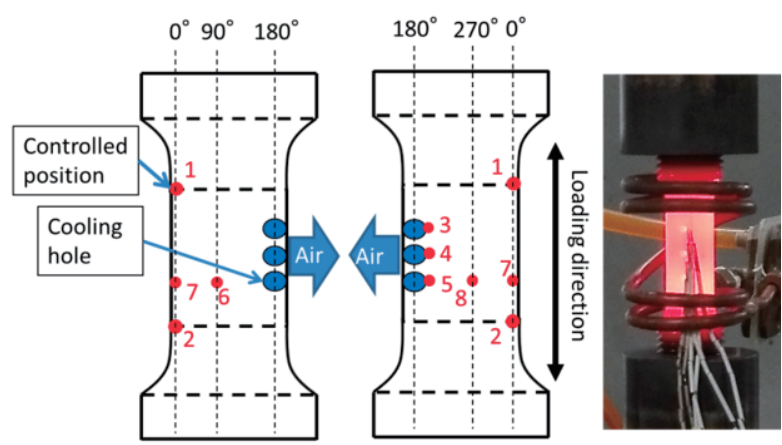

Fig.4 Temperature distribution around the cooling holes. 


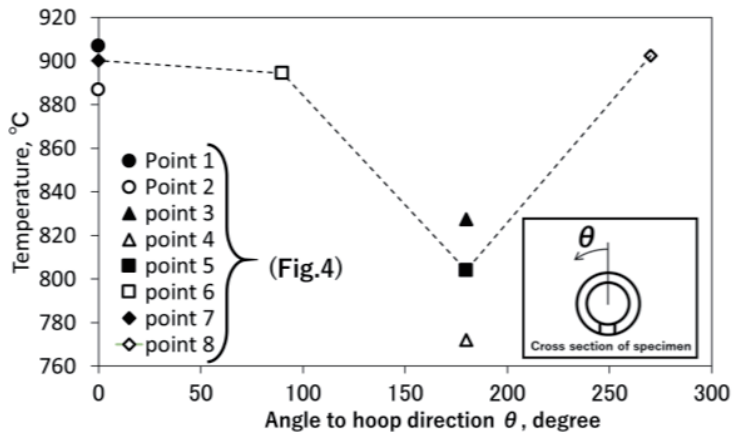

Fig. 5 Temperature distribution around the cooling holes, measured at the point " $\mathrm{P}$ " " during the HCF cycle in Fig.3(b)

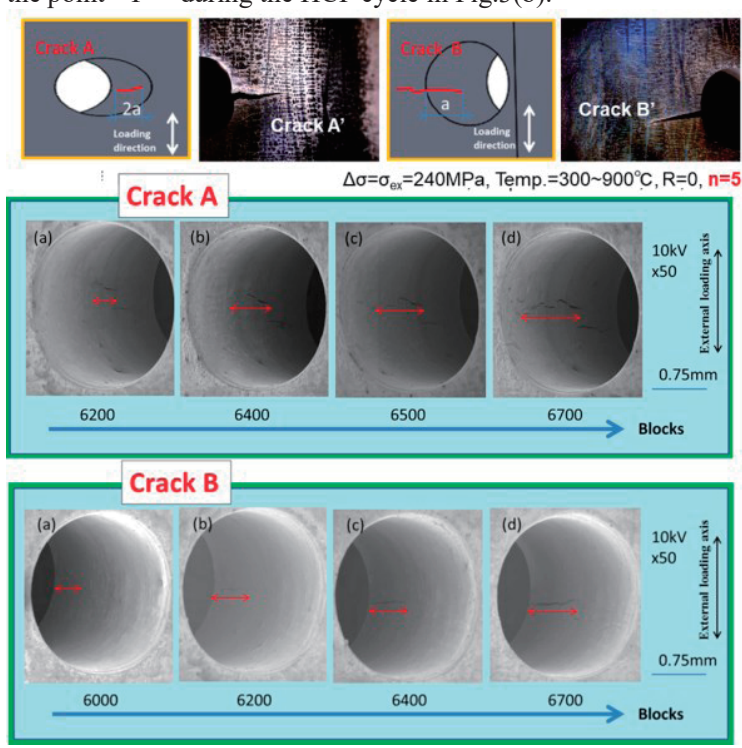

Fig.6 Crack initiation and propagation around the cooling hole.

3. 冷却孔からのき裂発生と初期成長

本研究で行った LC/HC-TMF 試験において観察された き裂の外観および発生位置を Fig.6に示す。き裂はすべて 下側の冷却孔から発生した。本研究では，き裂の形態と して, 冷却孔の肉厚中心部から生じた形態と (Crack A) と 試験片内面の泠却孔コーナーから生じた形態（Crack B） が観察された。それらを模擬的に Fig.7 に示す。またこ れらのき裂が成長し貫通き裂となったあと（Crack A’お よび Crack B’ ）の表面実体顕微鏡写真を Fig.6 左上に示 す。少なくともここで示す 2 つのき裂周囲において結晶 粒界は確認できず，一方向凝固材中の単一の結晶粒内を 伝ぱしている.

本研究ではこれらのき裂長さが試験片肉厚のオーダー に達し貫通する直後までの進展挙動に特に注目した。そ の際, 適用の適, 不適は別として, 現象を直感的に理解 するため, LC/HC-TMF 試験中の 1 ブロックあたりのき裂 進展速度に注目し，それらを見かけ上の応力拡大係数範 囲 $\Delta K_{L C F, a p p}$ との関係で調査した。 $\Delta K_{L C F, a p p}$ は暫定的に Newman-Raju の式により評価した ${ }^{10)}$.

$$
\Delta K_{L C F, a p p}=F(a, b) \Delta \sigma_{e x} \sqrt{\pi a}
$$

ここで $\Delta \sigma_{e x}$ は外負荷による応力範囲である．また $\boldsymbol{F}(\boldsymbol{a}, \boldsymbol{b})$ はき裂長さ $\boldsymbol{a}$ とき裂深さ $\boldsymbol{b}$ から定義される補正係数であ り (Fig.7 参照)，ここではき裂のアスペクト比を $\boldsymbol{a} / \boldsymbol{b}=1$ と

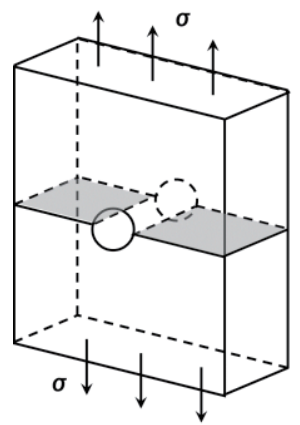

(a) Surface crack on side of circular hole (crack A)

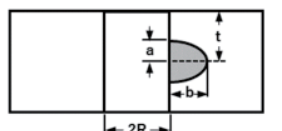

(b) Corner crack (crack B)

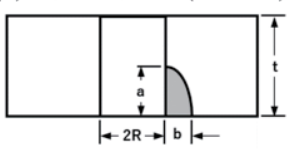

Fig.7 Stress intensity factor model for corner and surface crack at hole in finite plate under tension.

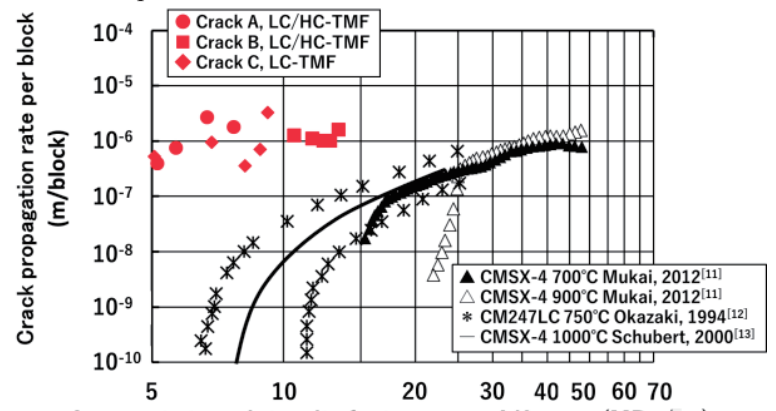

Apparent stress intensity factor range, $\Delta \mathrm{K}_{\mathrm{LCF}}$, app $(\mathrm{MPa} \sqrt{ } \mathrm{m})$

Fig.8 Relationship crack propagation rate and stress intensity factor range in terms of Eq. (1).

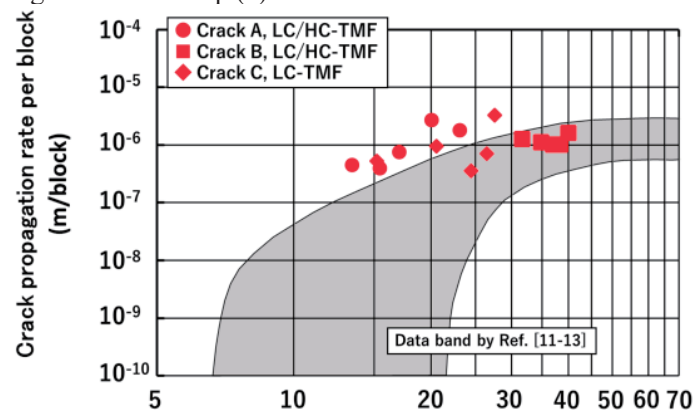

Apparent stress intensity factor range, $\Delta \mathrm{K}_{\mathrm{LCF}}$, app' $(\mathrm{MPa} \sqrt{\mathrm{m}})$

Fig.9 Relationship crack propagation rate and stress intensity factor range in terms of Eq. (2).

仮定して $\Delta \boldsymbol{K}_{L C F, a p p}$ を求めた.

Crack A と Crack B について得られた $d a / d N-\Delta K_{L C F}$ app 関係を Fig. 8 に示す. 図中には比較のため, LC-TMF 試験 で確認された貫通き裂（ここでは Crack C と称す），およ び $750^{\circ} \mathrm{C}$ から $1000^{\circ} \mathrm{C}$ 間でこれまでに報告されている等 温疲労き裂伝ぱ挙動の結果も併せて示した（これらの結 果は長さが数 $\mathrm{mm}$ オーダーのき裂を対象としている) ${ }^{11) ~ 13) . ~}$ Fig.8 より見かけ上の $\Delta \boldsymbol{K}_{\boldsymbol{L} C \boldsymbol{C} \text {, app }}$ で評価した場合, LC-TMF および LC/HC-TMF 試験における冷却孔周りのき裂進展 速度は一定温度下の疲労き裂進展速度よりも非常に大き いことが明らかである。

以上の結果を考察するにあたり，最初に冷却孔による 影響の 1 つである応力集中効果に注目する。本研究で扱 うき裂長さは発生直後のごく短いものであることから， ここでは応力集中係数 $\alpha_{e x}$ を加味した応力拡大係数範囲 を次式により評価した。

$$
\Delta K_{L C F, a p p^{\prime}}=F(a, b) \alpha_{e x} \Delta \sigma_{e x} \sqrt{\pi a}
$$

ここでは単軸負荷下の応力集中係数が 3 であることを考 慮し, 暫定的に $\alpha_{e x} \fallingdotseq 3$ とした. $\Delta K_{L C F, a p p}$, で Fig. 8 を再評 
価した結果を Fig.9 に示す。これより応力集中を考慮する ことで等温疲労き裂伝ぱ曲線に漸近していることが確認 できるが依然として従来までのデータ曲線と差がある. 以上の結果は冷却孔周りの熱機械的疲労き裂伝ぱ挙動の 評価に対して，等温疲労き裂の情報をそのまま適用する には限界があることを示している。

つぎに LC/HC-TMF 試験における高サイクル熱疲労重 畳の効果について検討する。これを検討するにあたって, Crack A および Crack B が成長し貫通き裂となった Crack A'を対象に調査を行った。 その結果を Fig.10 に示す. こ の目的のため Fig.10では, $\Delta \boldsymbol{K}_{L C F, a p p}, \fallingdotseq 15 \mathrm{MPa} \sqrt{\mathrm{m}}$ を一定 としたうえで，重畳させる HCF のサイクル数 $\boldsymbol{n}$ を 0 から 500 に変化させている. これより, 重畳 HCF サイクル数 $n$ の増加により 1 ブロックあたりのき裂進展速度が増加 することが確認できる.

\section{4. 冷却孔周囲のき裂伝ぱ挙動の考察}

前章では，機械的負荷のみを考慮した見かけ上の忘力 拡大係数範囲でき裂伝ぱ速度を評価してきたが実際には, 冷却孔周りにおいて温度勾配（Fig.5）によって誘起され る熱応力が生じているはずであり，この影響を無視して いる。そこで本章では外力に重畳される熱応力の観点か ら前章の結果を考察する.

\section{$4 \cdot 1$ 温度勾配誘起熱応力による応力拡大係数範囲への 影響}

本研究で生じる熱応力には LCF 区間中の熱応力と HCF 区間中の熱応力の 2 種類がある. そして，そこでは冷却 孔周りで生じる周方向と軸方向の温度分布によって誘起 された熱応力が生じているはずである。これらの熱応力 は外力との重畳によって，(i)疲労負荷中の応力振幅と(ii) 応力比を変化させる効果, および(iii)応力の多軸度を変化 させる効果をもつと考えられる。この様子を模式的に Fig.11 に示寸とともに，以下，各項目ごとにそれらの効果 を考察する。

(i)〜(iii)に共通する項目として冷却孔周囲の熱忘力を考 える. 冷却孔周囲の温度分布は 3 次元的に分布し複雑で

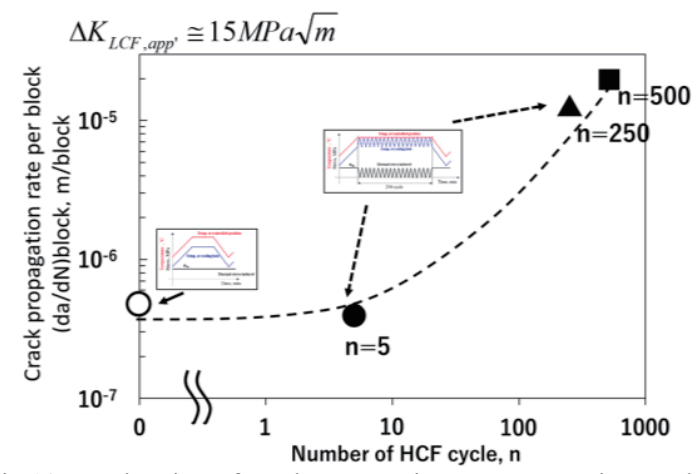

Fig.10 Acceleration of crack propagation rate as superimposed effect of HCF cycles.

Table 1 Rough estimation of remote thermal stress component at point $\mathrm{P}^{\prime}$.

\begin{tabular}{lllll}
\hline $\begin{array}{l}\sigma_{\mathrm{ex}}, \\
\mathrm{MPa}\end{array}$ & $\begin{array}{l}\sigma_{\text {th, }}(\mathrm{z}), \\
\mathrm{MPa}\end{array}$ & $\begin{array}{l}\sigma_{\text {th, }}(\theta), \\
\mathrm{MPa}\end{array}$ & $\begin{array}{l}\sigma_{\text {th }, \theta}(\mathrm{z}), \\
\mathrm{MPa}\end{array}$ & $\begin{array}{l}\sigma_{\text {th, },}(\theta), \\
\mathrm{MPa}\end{array}$ \\
\hline 240 & 17.7 & 111.8 & 83.9 & 30.1 \\
\hline
\end{tabular}

あるため，簡単化のため試験片厚さ方向の温度勾配を無 視し, 冷却孔周囲の温度が 2 次元的に分布していると考 えることにする. その際, 冷却孔周囲の遠方熱応力(remote thermal stress)の負荷軸方向と円周軸方向の成分を $\sigma_{t h, z}, \sigma$ th, $\theta$ と表記し (Fig.11)，それらの大きさをそれぞれの方向 の温度勾配によって生じる熱応力の線形和として近似す る 14). 文献 14)を参考にすると, Fig.12 中に示す熱応力の 各成分は

$\sigma_{t h, z}(z)=\frac{\sqrt[4]{3\left(1-v^{2}\right)}}{4\left(1-v^{2}\right)} \frac{\sqrt{r_{i} t}}{l_{0}} E \beta \Delta T$

$\sigma_{t h, z}(\theta)=\frac{1}{3} \beta \Delta T E$

$\sigma_{t h, \theta}(z)=\left\{\frac{\left(1-v^{2}\right)}{\sqrt{3\left(1-v^{2}\right)}}+v\right\} \frac{\sqrt[4]{3\left(1-v^{2}\right)}}{4\left(1-v^{2}\right)} \frac{\sqrt{r_{i} t}}{l_{0}} E \beta \Delta T$

$\sigma_{t h, \theta}(\theta)=\frac{A_{H} E \Delta W}{\left(A_{H}+A_{L}\right) W_{0}}$

と簡易評価される $\left.{ }^{15)} 17\right)$ 。これら式中の $\boldsymbol{E}, \beta, \nu$ はそれ ぞれヤング率, 熱膨張係数およびポアソン比であり, 中 空試験片の $r_{i}$ は内半径, $\boldsymbol{t}$ は肉厚, $\boldsymbol{l}_{\boldsymbol{0}}$ は標点部長さ, $\boldsymbol{W}_{\boldsymbol{0}}$ は 円周長さ， $\boldsymbol{A}_{\boldsymbol{H}}$ および $\boldsymbol{A}_{\boldsymbol{L}}$ は高温部 $\left(900^{\circ} \mathrm{C}\right)$ および低温部 $\left(770^{\circ} \mathrm{C}\right)$ が占める縦断面積であり， $A_{H} \fallingdotseq A_{L}$ である.

(a)

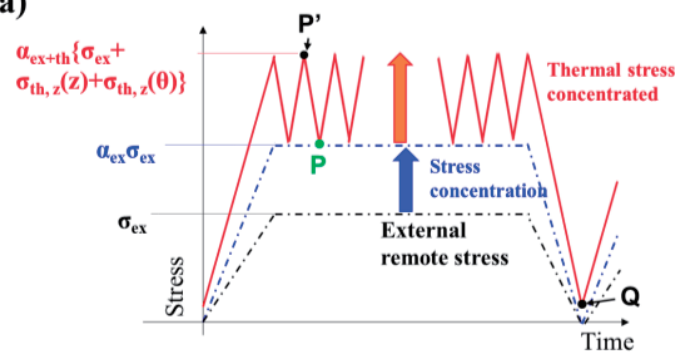

(b)

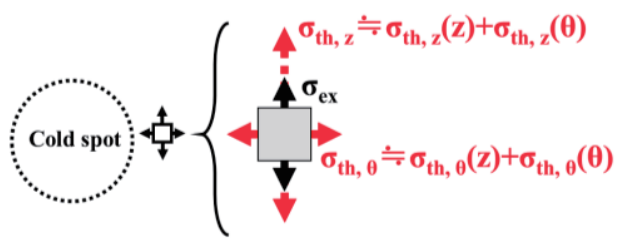

Fig.11 (a)Schematic diagram on local thermal stress in the present LC/HC-TMF test when thermal stress is superimposed on mechanical stress, (b)remote thermal stress near the cold spot at point P'.
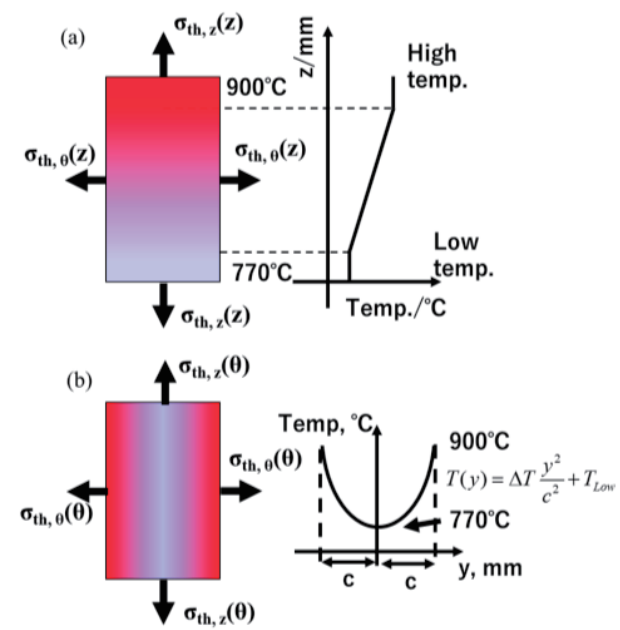

Fig.12 Simplified model of thermal stress based on the temperature distribution in Fig.5, (a) the model with temperature distribution in the axial direction of cylinder, (b) the model with temperature distribution in the circumferential direction of cylinder. 
上式の簡易モデルによって， HCF サイクル中の点 $\mathrm{P}^{\prime}$ の 時点（Fig.3(b), 11 参照）において付加的に生じる熱応

力の推定值を Table 1 に示す. 計算にあたっては Fig.5 の実測結果と物性值として, $\boldsymbol{E}=150 \mathrm{GPa}, \boldsymbol{\nu}=0.3, \quad \boldsymbol{\beta}$ $=1.48 \times 10^{-5} \mathrm{~K}^{-1}$ を用いた. Table 1 より, 各熱応力は外力 $\sigma_{e x}$ に対して無視できない值となっている。なおこれらの熱 応力には冷却孔周囲の応力集中効果は考慮されていない

つぎに，本節冒頭で述べた熱応力の 3 つの効果につい て検討する.

(i)熱応力の重畳による疲労応力振幅の変化

Fig.3(b)あるいは Fig.11 に模擬的に示すように, Table 1 に示した熱灾力は LCF 期間中では点 $\mathrm{P}$ 'において生じ, これは LCF 中の $\mathrm{z}$ 軸方向の遠方場応力振幅をみかけ上の 值 $\Delta \sigma_{e x}$ から $\Delta \sigma_{e x}+\Delta \sigma_{t h, z}(z)+\Delta \sigma_{t h, z}(\theta)$ 一と増加させる 効果となる. この応力の総和は応力集中によってさらに 割増させられる。この割増度を $\boldsymbol{\alpha}_{\text {ext th }}$ と表記すると, $\boldsymbol{\alpha}_{\text {ext th }}$ は主応力の多軸度を表す係数 $\lambda\left(\equiv \sigma_{2} \sigma_{1} ， \sigma_{1}\right.$ と $\sigma_{2}$ は 外力方向とそれに垂直な方向の主応力を表す代表記号) を用いて

$$
\alpha_{e x+t h}(\lambda) \doteqdot 3-\lambda
$$

と近似できる. 式(4)は応力集中係数に対する多軸性を表 す近似式である ${ }^{18)}$. そして $\lambda$ の值は Fig.11 中の点 P, P' およびQで異なる值をとり，それぞれ

$$
\begin{aligned}
& \lambda_{P^{\prime}} \fallingdotseq \frac{\sigma_{t h, \theta}\left(\theta, P^{\prime}\right)+\sigma_{t h, \theta}\left(z, P^{\prime}\right)}{\sigma_{e x}+\sigma_{t h, z}\left(\theta, P^{\prime}\right)+\sigma_{t h, z}\left(z, P^{\prime}\right)} \\
& \lambda_{P} \fallingdotseq 0 \\
& \lambda_{Q} \fallingdotseq \frac{\sigma_{t h, \theta}(\theta, Q)+\sigma_{t h, \theta}(z, Q)}{\sigma_{t h, z}(\theta, Q)+\sigma_{t h, z}(z, Q)}
\end{aligned}
$$

と表される。式(4)，(5)を組み合わせると，本研究の LC-TMF 負荷中の LCF 負荷による応力拡大係数は式(2)を 補正して

$$
\begin{aligned}
& K_{L C F, e x+t h}=\left\{\alpha_{e x+t h}\left(\lambda_{P^{\prime}}\right) \mid \sigma_{e x}+\sigma_{t h, z}\left(\theta, P^{\prime}\right)+\sigma_{t h, z}\left(z, P^{\prime}\right)\right] \\
& \left.-\alpha_{e x+t h}\left(\lambda_{Q}\right)\left[\sigma_{t h, z}(\theta, Q)+\sigma_{t h, z}(z, Q)\right]\right\} F(a, b) \sqrt{\pi a}
\end{aligned}
$$

(ii)熱応力の重畳による LCF 期間中の応力比の変化

Table 1 の熱応力の作用により, LCF と HCF 期間中に生 じる繰返し負荷の応力比 $\left(\boldsymbol{R}_{L C F}, \boldsymbol{R}_{H C F}\right)$ は，それぞれ

$$
\begin{aligned}
& R_{L C F}=\frac{\left.\alpha_{e x+t h}\left(\lambda_{Q}\right) \mid \sigma_{t h, z}(\theta, Q)+\sigma_{t h, z}(z, Q)\right]}{\alpha_{e x+t h}\left(\lambda_{P^{\prime}}\right)\left[\sigma_{e x}+\sigma_{t h, z}\left(\theta, P^{\prime}\right)+\sigma_{t h, z}\left(z, P^{\prime}\right)\right]} \\
& R_{H C F}=\frac{\alpha_{e x} \sigma_{e x}}{\alpha_{e x+t h}\left(\lambda_{P^{\prime}}\right)\left[\sigma_{e x}+\sigma_{t h, z}\left(\theta, P^{\prime}\right)+\sigma_{t h, z}\left(z, P^{\prime}\right)\right]}
\end{aligned}
$$

となる。これらの応力比はき裂伝ぱに対して影響するの で，それを有効応力拡大係数 $\boldsymbol{\Delta} \boldsymbol{K}_{\text {eff }}$ の概念を導入して簡便 評価することにする ${ }^{19)}$. すなわち

$$
\Delta K_{e f f}=\frac{\Delta K_{L C F, e x+t h}}{\left(1-R_{L C F}\right)^{\gamma}}
$$

ここで $\boldsymbol{y}$ は $\boldsymbol{R}$ の影響の程度を示寸材料定数であり，参考 文献 20)より $\gamma=0.36$ を用いることにする.

以上より LC-TMF 試験中の LCF 期間中の有効応力拡大 係数範囲は，それぞれ

$$
\begin{aligned}
& \Delta K_{L C F, e f f}=\left\{\alpha_{e x+t h}\left(\lambda_{P^{\prime}}\right) \mid \sigma_{e x}+\sigma_{t h, z}\left(\theta, P^{\prime}\right)+\sigma_{t h, z}\left(z, P^{\prime}\right)\right\rfloor \\
& \left.-\alpha_{e x+t h}\left(\lambda_{Q}\right)\left[\sigma_{t h, z}(\theta, Q)+\sigma_{t h, z}(z, Q)\right]\right\} F(a, b) \sqrt{\pi a} /\left(1-R_{L C F}\right)^{\gamma}(10) \\
& \text { 一方 }
\end{aligned}
$$

$$
\begin{aligned}
& \Delta K_{H C F, e f f}=\left\{\alpha_{e x+t h}\left(\lambda_{P^{\prime}}\right) \mid \sigma_{e x}+\sigma_{t h, z}\left(\theta, P^{\prime}\right)+\sigma_{t h, z}\left(z, P^{\prime}\right)\right] \\
& \left.-\alpha_{e x} \sigma_{e x}\right\} F(a, b) \sqrt{\pi a} /\left(1-R_{H C F}\right)^{\gamma}
\end{aligned}
$$

(iii)熱応力による応力の多軸度の変化

この効果の一部については上述の項目(ii)においてすで に言及した。ただし，その他の付加的効果もある。すな わち，式(10)と(11)は，いわば単軸応力状態におきかえて 近似評価したものであるが，熱応力は式(1)を出発点とす る一連の力学量（ $\Delta \boldsymbol{K}_{\text {LCF,app }}$ など） そのものを変化させる 効果もある. 応力拡大係数に対する多軸負荷場の効果は Newman によって数值計算されており 21), 本研究に対す るその視点からの影響は捕捉 1 で記載した.

以上の検討をふまえ, 式(10), (11)を介して本研究の伝 ぱ速度を再整理した結果を Fig.13 に示す。これより，温 度勾配に誘起された熱応力が及ぼす 3 つの影響（疲労負 荷中の応力振幅, 応力比, 応力の多軸度を変化させる効 果）を考慮することにより, 本研究で測定された LC-TMF 中の冷却孔からのき裂の初期成長を, 一定温度下の疲労 き裂進展速度の知見をもとにある程度予測できると考え られる。

\section{$4 \cdot 2 \mathrm{HCF}$ 重畳効果}

前節の議論では，LCF 期間のき裂伝ぱ速度のみに注目 してきたが，それに重畳される HCF 期間中においても， その条件によっては無視できない量のき裂の進展が起こ り得る (Fig.10 参照)。これについて考えるため, つぎの ような伝ぱ規準式を考えることにする.

$$
\begin{aligned}
& \left(\frac{d a}{d N}\right)_{\text {block }}=\left(\frac{d a}{d N}\right)_{L C F}\left(\text { when } \Delta K_{H C F} \leq \Delta K_{t h}\right) \\
& \left(\frac{d a}{d N}\right)_{\text {block }}=\left(\frac{d a}{d N}\right)_{L C F}+\int_{n}\left(\frac{d a}{d N}\right)_{H C F} d N
\end{aligned}
$$

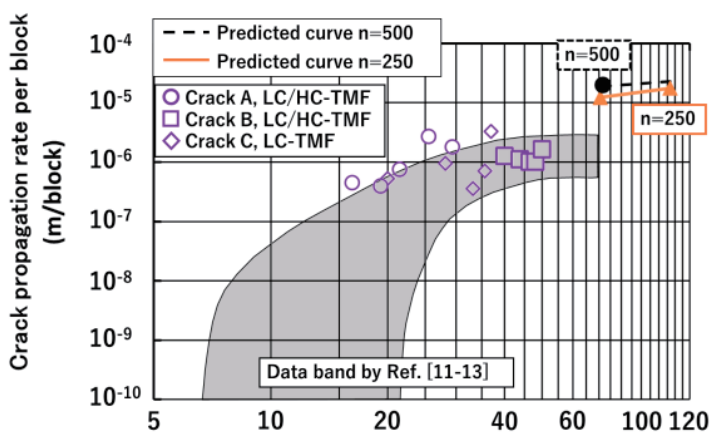

Stress intensity factor range superimposed thermal stress, $\Delta \mathrm{K}_{\mathrm{LCF}, \text { eff }}(\mathrm{MPa} \sqrt{\mathrm{m}})$

Fig.13 Relationship crack propagation rate and stress intensity factor range in terms of Eq. (11). 
式(12)中の $\boldsymbol{\Delta} \boldsymbol{K}_{\boldsymbol{t} \boldsymbol{h}}$ はき裂伝ぱに対する下限界であり, $\boldsymbol{\Delta} \boldsymbol{K}_{\boldsymbol{t} \boldsymbol{h}}$ $\doteqdot 12 \mathrm{MPa} \sqrt{\mathrm{m}}$ である ${ }^{12)}$.

4.1 節で導入した各評価式をベースに式(12)による予測 結果を Fig.13 中の破線および実線で示した。計算にあた つては $(d a / d N)_{L C F}$ の実測值を用いた。これより，予測結果 と実験結果にはまずまずの一致がみられる.

以上の結果より，LC-TMF 負荷のうえに HC-TMF が重 畳されたときのき裂進展速度は式(12)をベースにある程 度予測することができると考えられる。

\section{5 結 言}

試作・改良した実環境模擬試験装置を用いて，不均一 な温度場下にあるガスタービン翼中の冷却孔まわりの熱 機械的疲労破損挙動を実験的に調査した。その際，特に 準定常な熱サイクルによって生ずる付加的な熱疲労破損 現象に注目し，その効果を破壊力学的に検討した.

得られた結果を要約すると,

（1）準定常な熱サイクルが定常的熱機械的負荷に重畳さ れると, それがない場合と比べ, 微小き裂の進展速 度は有意に加速する．そこには準定常熱サイクル期 間中に生ずる付加的な熱応力が大きな役割を果たし ていることを実験的に示し，それがもたらす複数の 効果について検討した。

（2）温度勾配があり，かつ低サイクル熱機械的疲労負荷 と高サイクル熱疲労負荷が重畳される条件の下にお けるき裂の初期成長挙動を予測する方法を提示した.

本研究の遂行にあたり, 科学研究費補助金（基盤 (A)(Category A, No. 16H02304). ) の援助を受けた. 記して 感謝の意を示す.

\section{Appendix A}

冷却孔がある無限板における応力拡大係数への応力の 多軸度の影響について記述する. Fig.14 に Newman らに よって調査された各多軸度入における無次元応力拡大係 数 $\boldsymbol{F}$ と無次元距離 $\boldsymbol{c} / \boldsymbol{R}$ との関係を示す。ここで $\mathrm{c}$ は冷却 孔の半径長さを含むき裂長さであり, $\boldsymbol{c}=\boldsymbol{b}+\boldsymbol{R}$ である（図 中の概略図参照)。この図によれば，冷却孔の応力集中と 遠方応力の多軸度 $\lambda$ の值に依存して応力拡大係数值が変 化するが，その影響度は冷却孔からの成長量が増加する につれて消失する.この結果を本研究の結果（Fig.13）に 適用すると横軸の值は 10\% 20\%変化することになる. こ の変化量は Fig.13 から導出された知見を変えるものでは ない.

\section{参 考 文 献}

1) H. Kazempour-Liacy, S. Abouali and M. AkbariGarakani, "Failure analysis of a first stage gas turbine blade", Engineering Failure Analysis, Vol. 18, pp.517-522 (2011).

2) K. Mukai and Y. Itoh, "Hydraulic energy system to improve quality of energy grit", Toshiba Review, 58, (2003).

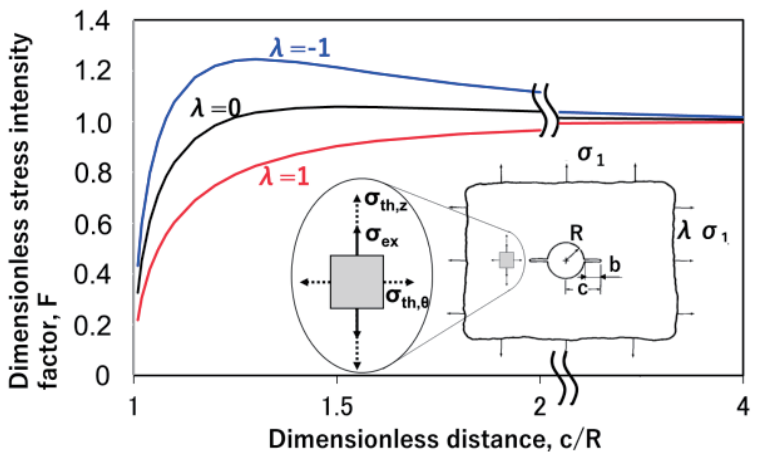

Fig.14 Stress intensity correction factors for cracks emanating from cooling hole in an infinite plate subjected to biaxial load ${ }^{18)}$.

3) T. Brendel, E. Affeldt, J. Hammer and C. Rummel, "Temperature gradients in TMF specimens. Measurement and influence on TMF life", International Journal of Fatigue, Vol.30, pp.234-240, (2008).

4) H. Saeki, M. Matsushita, Y. Fukuyama, T. Yoshida, T. Yokokawa and H. Harada, "Development of a virtual gas turbine system for a 1700 degree class GT", Gas Turbine Society of Japan, Vol.36, No.4, pp.283-288, (2008).

5) T. Yoshida, "Cooling technology", Bulletin of Gas Turbine Society of Japan, Vol.25, No.97, pp.29-34, (1997).

6) H. L. Bernstein, T. S. Grant, R. C. McClung and J. M. Allen, "Thermomechanical fatigue behavior of materials", ASTM STP 1186, pp.212-238 (1993).

7) N. Kasahara, H. Tkasho and A, Yacumpai, "Structural response function approach for evaluation of thermal striping phenomena”, Nuclear Engineering and Design, Vol. 212, pp. 281-292 (2002).

8) M. Okazaki, S. Yamagishi, M. Milton and M. Sekihara, "Small crack propagation behavior during thermo-mechanical creep-fatigue loading of $\mathrm{Ni}$ based superalloy specimen under non-uniformly distributed temperature condition", Materials at High Temperature, Vol.32, No.3, pp.293-297, (2015).

9) Y. Yonakuni and M. Okazaki, "Thermo-mechanical fatigue failure behavior of thermal barrier coatings specimen under transient thermal response", Gas Turbine Society, Vol.45, No. 6, pp.458-464, (2017).

10) J. C. Newman, Jr. and I. S. Raju, "Stress intensity factor equations for cracks in three-dimensional finite bodies", NASA Technical Memorandom 83200, pp.1-49 (1981).

11) H. Kagawa and Y. Mukai, "The effect of crystal orientation and temperature on fatigue crack growth of Ni-based single crystal superalloy”, Superalloys 2012, pp.225-233, (2012).

12) M. Okazaki, H. Yamada and S. Nohmi, "Temperature dependence of the intrinsic small fatigue crack growth behavior in Ni-base superalloys based on measurement 
of crack closure", Metallurgical and Materials Transaction, Vol.27, No.4, pp1021-1031, (1996).

13) F. Schubert, T. Rieck and P. J. Ennis, "The growth of small cracks in the single crystal superalloy CMSX-4 at 750 and $1000^{\circ}$ C", Superalloy 2000 , pp. 341-346, (2000).

14) R. F. Barron and B. R. Barron, "Design for thermal stresses", New York, John Wiley and Sons (2012).

15) P. Timoshenco, "Theory of plates and shells", pp. 498-501 (1959).

16) S. Taira, "Thermal stress and thermo-mechanical fatigue", Nikkan Kogyo Shimbun, pp.21-22 and 245-247, (1976).

17) S. Timoshenko, "Theory of elasticity", McGraw-Hill College, pp.449-455, (1970).

18) W. D. Pilkey and D. F. Pilkey, "Stress concentration factors", Willey, (2008)

19) K. Walker, "The effect of stress ratio during crack propagation and fatigue for 2024-T3 and 7075-T6 aluminum”, ASTM STP 462, pp.1-14, (1970).

20) Y. Yamada and J. C. Newman, "Crack closure under high load-ratio conditions for inconel-718 near threshold behavior", Engineering Fracture Mechanics, 76, pp.209-220, (2009).

21) J. C. Newman Jr, "An improved method of collocation for the stress analysis of cracked plate with various shaped boundaries", Langley Research Center Hampton, Va. 23365, (1971). 